\title{
THE EFFECTIVENESS OF COOPERATIVE LEARNING APPROACH IN VOCABULARY DEVELOPMENT OF INTERMEDIATE STUDENTS
}

\author{
Aniqa Rafique \\ MS Scholar, \\ Department of Sciences and Humanities, National University of Computer and Emerging \\ Sciences Lahore, \\ Punjab, Pakistan \\ Email: aniqarafiq4@gmail.com
}

\section{Zahida Mansoor}

Assistant Professor,

Department of Sciences and Humanities, National University of Computer and Emerging

Sciences Lahore,

Punjab, Pakistan

Email: zahida.mansoor@nu.edu.pk

\section{Tayyaba Bint-e-Mehmood}

Lecturer,

Department of English, University of Central Punjab Lahore,

Punjab, Pakistan

Email: tayyaba.mehmood@ucp.edu.pk

\begin{abstract}
The study aims to investigate the effectiveness of cooperative learning approach in the vocabulary development of intermediate students. Vocabulary provides a sound grip to an individual in building up their confidence. While getting admission in any discipline in Pakistan, one-third of the admission tests focus on English language proficiency and majority of the students are unable to understand the language of the tests owing to insufficient vocabulary knowledge and the failure to perform well has been frequently attributed to teacher-centered pedagogies and traditional classrooms (Mahmood \& Ahmad, 2010). The study uses quantitative research design. The sample of eighty students studying at intermediate level in a local government college was selected using the purposive sampling technique. Data was collected using pre-test and post-test. The results of the research reveal that the cooperative learning approach is super useful in word bank development as the students performed better in Collaborative Learning Environment.The study recommends that the teacher trainings for the intermediate level be improved in such a way that they incorporate the effectiveness of cooperative learning approach, thus assessing the
\end{abstract}


needs and requirements of a particular class of the intermediate students to provide them with an effective learning experience.

\section{KEYWORDS}

Vocabulary; Vocabulary Development; Cooperative Learning; Traditional Learning

\section{INTRODUCTION}

In Pakistan, people who use English language are increasing in number day by day. The use of English has been a part of Pakistan's community for a long time now and is also serving as the official language of the country. Despite its importance, learners in Pakistan face a lot of difficulties while learning it, irrespective of the area of English language; a majority of issues are reported by language users in their vocabulary development (Dar, 2015).

Vocabulary acquisition is a challenge that learners face during the process of second language learning. (Dovey, 2010). No specific emphasis is given on language competency especially vocabulary in traditional classrooms (Khan \& Ahmad, 2014). It is very important to learn vocabulary because when we are used to write comprehension it is use as a strong predicator. If the word is recognized by mind a student who has strong vocabulary skills he or she can recognize a new word in text easier and faster (Montasser, 2014). And it has been proved that insufficient knowledge of vocabulary leads to difficulties in understanding of second language (Dar, 2015).The use of traditional methodologies in language teaching hinder the learning process of language learners due to which they are unable to achieve high level proficiency which is a basic requirement not only for higher education, but also better career prospects. Consequently, students turn out to be incompetent their practical use of English language.Owing to this, students face difficulties in passing the entry tests for higher education,especially in vocabulary section which has created dissatisfaction. (Shamim, 2011).

CL approach was introduced after the mid of 1960s and its application in the classroom teaching find its root after 1970s when the United States began to start designing and studying CL models for classroom settings. Liang, (2002). CL approach has been applied in almost all school, colleges and universities due to its rich theory, research and actual use of the classroom and this approach is claimed to be an effective teaching approach in second language education by scholars (Badger \& Warsi, 2009). Cooperative learning is all about that students are learning in a group and teacher is helping them as a facilitator. According to Oxford, (1997), it has been stated that cooperative learning is not about to engage students in a small group but it more than that having highly structured based techniques which evolved sociological and psychological which leads to learn and obtain a learning goal. 
Result analysis of intermediate exam highlights the fact that students' results in the subject of English language suffer because of their inadequate vocabulary skills. Soon after intermediate, students appear in the entry tests to get admission in higher education. These tests are conducted in English language and these tests form the basis of the medium used to test the proficiency of the students in English language (Badger \& Warsi, 2009). According to Mansoor, S. (2003), the admission test session students reported that they face difficulties in the English part especially in synonyms and paper design is based on the rote learning rather than their cognitive abilities due to which they face difficulties in comprehending language. So, there is need to be introduced such kind of strategies that can be helpful in developing students interest in vocabulary development (Siddique \& Singh, 2016).

It highlighted the cooperative learning approach for teachers on effective vocabulary learning strategies to employ in intermediate classrooms. This study has also suggested the new ways of language learning and teaching experiences for English language teachers.

\section{LITERATURE REVIEW}

Throughout the world, English is being learnt, spoken and read widely and it has become the most dominant language among the world (Jenkin, 2006).To learn a second language effectively, one must have the knowledge of vocabulary and it helps the learners to comprehend meaning, spellings and derivations (Fan, 2003). While learning second language, one of the most significant challenges that learners come across is vocabulary. (Heggins, 2015).

Researchers have given particular attention to vocabulary learning as it is basically required to improve all the four language types. Recently, vocabulary is considered much important as it aids to enhance reading ability. Wolley (2010) demonstrated that those who are eager to learn language cannot understand a given passage because of the lack of vocabulary.Teachers do not feel confident enough to employ best techniques in vocabulary teaching, not even sure of from where to start to stressing on instruction learning which makes it quite problematic teach vocabulary (Berne \&Blachowicz, 2008).Houng (2006) in Vietnamese university studied vocabulary learning in collaborative learning and the findings showed that group work improves vocabulary learning. Newton (2001) carried different communication tasks to study vocabulary learning. Cooperative learning in pre-task was one of these tasks in which students were asked to find meanings of words in dictionary cooperatively. And the results found that cooperative learning in the pre task stage of the lecture played a significant role in improving vocabulary learning process.

In 2012, a research was conducted to explore STAD's impact on students' 
achievement, motivation, and attitude in the field of economics. Van Wyk (2012) used three research tools which include Test of Economics Literacy, an Economic Model Test and a motivation scale for conducting this study. The research method that he used was Quasi-experimental, for which he had to conduct pre-test and Posttest. The outcomes of the study revealed that STAD enhanced Learners' positive attitude as compared to direct instruction. It also brought about better achievemenets and also motivated learners to learns more in the field of economics. Through cooperative learning, the learners are motivated towards learning more efficientlyso it is highly useful for not only acquisition of language but also better developing communication skills in creativity and teamlead (You \&Lv, 2014).Zarei and Keshavarz (2011) experimented Iranian learners to analyze the effects of two CL models on vocabulary learning and reading comprehension. The results showed that non cooperative control groups performed much less and teaching with CL models was a success.

Fekri (2016) researched on the influence of cooperative and competitive techniques in learning language in Iranian context. The findings showed that English vocabulary development of Iranian EFL intermediate students was improved by employing cooperative and competitive learning strategies. In comparison of the competitive and cooperative learning, the outcomes of independent t-test explored that learners in the experimental group of the cooperative strategy performed much better than the students in the experimental group of competitive strategy. Bilen and Tavil, (2015) formulated their study based upon the determination of the effect of CL techniques on the vocabulary of the students of 4th grade. The aim was to find out the behavior of the learners in the experimental group towards cooperative learning and the findings were in the favor of cooperative learning regarding vocabulary development.

Ercan (2009) was more interested in knowing which vocabulary teaching method, cooperative or traditional, was more influential in improving the vocabulary recognition of preparatory class young learners. He administered pre and posts to both the groups; experimental and the control group. The findings revealed both groups performed better in post tests, however, the experimental group scored comparatively higher. Similarly,another study carried out by Çokparlamış (2010) aimed at finding out the impact of cooperative learning in viewing the fifth grade syllabus objectives and student view of classes, while making use of cooperative learning methods. The findings of pre and post test showed a considerable difference between the control group and the experimental group. It was obvious that the experimental group improved their skills more speedily during the study. The analysis of the diaries also showed that the students enjoyed cooperative learning more. 
Windasari (2012) conducted research. The study based on grade 8 students and STAD approach was used to improve their English specially vocabulary. It has been found that grade VIII students of SMP Negeri 19 Palu improved with the use of students' team achievement division method. Despite learning new words, we still cannot use all of them $m$ Even if we acquire the words, we meaningfully. Teachers should explore systematic options to help students in learning vocabulary as reading definitions or going through dictionaries and listening to teachers are not much effective in vocabulary building. Despite the advantages of collaborative learning, there are also arguments against collaborative learning

\section{RESEARCH OBJECTIVE}

1. To investigate the effect of CL approach in the vocabulary development of Intermediate students in the Pakistani context

\section{RESEARCH QUESTION}

1. What is the effect of cooperative learning in vocabulary development of the Intermediate students?

\section{RESEARCH HYPOTHESIS}

1. There is a need to determine effective strategies to support vocabulary development for the intermediate students in Pakistan.

\section{RESEARCH METHODOLOGY}

The study explored the effect of cooperative learning approach in vocabulary development of intermediate students. To achieve the intended goal, the study uses quantitative research method. The quantitative data comprised of students' in-class performance and responses on learning vocabulary.The current study is experimental in its nature. The current study also comprised of pre-test, post-test.

\section{Theoretical Framework}

The framework for the study was adopted from the cooperative learning approach, introduced by Slavin (1995). The Student Teams Achievement Divisions (STAD) strategy was successfully applied in different research projects as an effective teaching technique for academic purpose (Van Wyk, 2010). This model was appropriate for the scope of the study as it encompassing the cooperative learning strategies

\section{Student Team Achievement Division (STAD)}

(STAD)Student team achievement division is based upon the learning technique in which small sets of learning students having different capability are obliged to work together in a group in order to achieve a collective learning goal. Slavin and his 
colleagues at John Hopkins University proposed this strategy (Innovative Learning, 2009), in which four to five students having different gender, ethnicity and capability to learn, are assigned to work under one team. The responsibility of teacher is to give them a task and they need to work collectively in their teams and team performance is analyzed on the basis that every team member has mastered the given lesson. Their assessment is based upon the individual quizzes and without each other's help. The scores are compared with their quiz results that were conducted in the past and grade points are also granted on the basis of their ability to come across or surpass their previous performance.

\section{Population}

The students of 2nd year in a public sector college were the target population of the study. The students had no knowledge of working in cooperative groups or of cooperative learning frameworks.

\section{Sample}

The sample for the study included 80 students enrolled in the 2nd year of intermediate at a public sector college in Lahore were selected. The purposive sampling technique was employed to test a specific population and it involves the identification and selection of a person or a group that have the principle knowledge or the owe experience with a particular phenomenon of interest (Cresswell\& Clark, 2011). Purposive sample of students from the public sector college enrolled in 2nd year were selected because intermediate students are mature enough to work in group collaboratively to achieve specific goal.

\section{Instrument}

Data was collected using the students' tests.In order to find the effectiveness of cooperative learning approach, test was designed based on the entry test format and from the curriculum the students were studying. The test was multiple choices based on vocabulary items. The pre-test was taken from the students to determine prior knowledge. The treatment was given by introducing (STAD) strategy into the classroom. This strategy provided encouragement to the team members to perform well in individual and collaborative tasks given to them. Student team achievement division is based upon five modules i.e. team work, quiz assessment, class presentation, team recognition and improvement as an individual. The treatment was developed around the core components of STAD.Post-test was conducted after a 5 week treatment.

\section{Data Analysis Procedure}

The objective was to determine the effect of cooperative learning approach in vocabulary development. To achieve the objective, after collecting data from pre-test 
and post-test, the average scores of both tests were compared by the application of paired T-test. Paired T-test was used in order to compare the variability between pretest and post-test. For quantitative data analysis (McDonald, 2008). SPSS (Statistical package for Social Sciences) was employed.

\section{DATA ANALYSIS AND RESULTS}

The study explored the effectiveness of cooperative learning approach in vocabulary development of intermediate students. This chapter provides results and analysis of the data collected through pre-post test. The data obtained through students' pre-test and post-test was analyzed quantitatively to determine the effectiveness of CLA in vocabulary development.

\section{Results of Pre-Post Test}

In order to determine the previous knowledge of the intermediate students about vocabulary, pre-test was conducted. Post-test was conducted after giving treatment based on the cooperative learning activities to the participants. Paired t-test was applied to analyze the difference in the students' pre-test and post-test scores before and after the treatment. In order to answer the first question, "effectiveness of cooperative learning approach in vocabulary development of intermediate students", the following table illustrates the comparison of pre-test and post-test by demonstrating mean and standard deviation.

Ho: There is no significant difference in the vocabulary development of pre-test and post-test.

H1: There is a significant difference in the vocabulary development of pre-test and post-test.

Table 1: Paired Samples Test

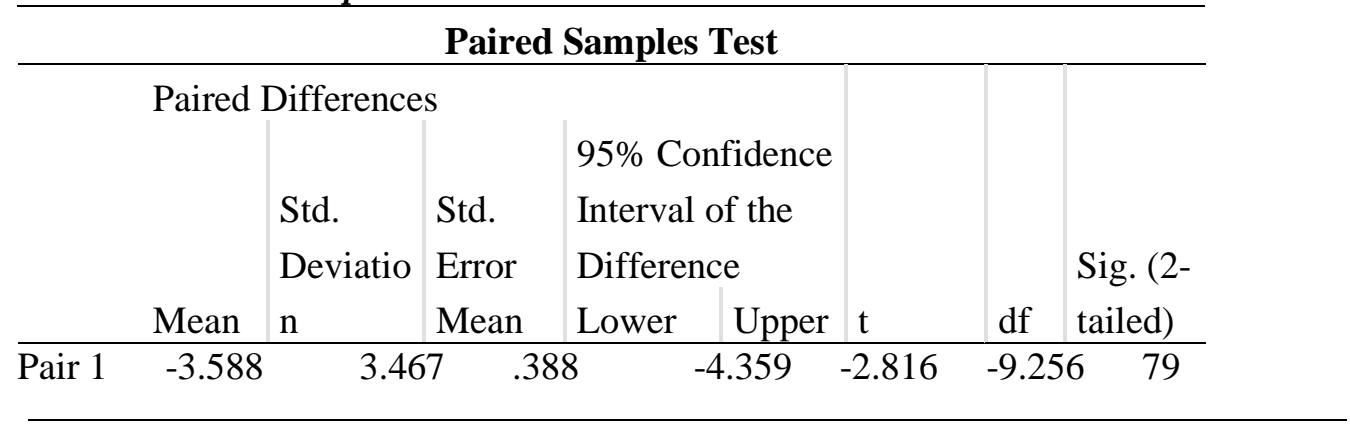

Level of Significance: $\alpha=0.05$

$\mathrm{H} 0$ is computed by applying paired t-test and results are presented in the Table 1 . From the results in Table 1, it is observed that $\mathrm{P}$ value $=0.000$ which is less than $\alpha=0.05$. Hence statistics showed that $\mathrm{H} 0$ is rejected. The results indicated a difference 
between the scores for pre-test and post-test $(\mathrm{M}=-3.58, \mathrm{SD}=3.46)$. There is insufficient evidence to support the null hypothesis. Hence it is concluded that treatment is effective such as there was difference in the students' pre-test and posttest scores before and after the treatment.

The results obtained from the paired samples test favored the alternative hypothesis $\mathrm{H} 1$, demonstrating that the intermediate students showed an improvement learning through cooperative learning approach which signifies their inclination towards this approach in order to develop their vocabulary.

\section{DISCUSSION}

The present study revealed that CLA was found to be influential in English vocabulary development of the intermediate students. It is an effective approach for the students to learn vocabulary thus improving their confidence and motivational skills. Post treatment effect shows as significant difference between the marks of pretest and post-test.

Moreover, Student Team Achievement Division (STAD) was considered useful teaching approach in the classroom to improve students' vocabulary knowledge. The instructions of teachers about STAD played a vital role in developing the interest of students by collaborating in groups and teams to make students proficient. The students were given instructions thus making them able to work together by helping their peers. The students improved their vocabulary by using different activities and found word webbing the most interesting activity.The students were satisfied with the planning and monitoring process used in cooperative learning and suggested that it is adaptable for normal classroom teaching.

The research question investigated the extent to which cooperative learning approach is effective in vocabulary development of intermediate students. The outcome of the pre-test and post-test scores on students' vocabulary development revealed a difference between the scores, large enough to reject the null hypothesis "There was no significant difference between the scores of before and after treatment". The results indicate that using the STAD and CLA in the classroom were successful in developing the vocabulary of the students. These findings support earlier studies by Newton (2001) and Houng (2004), who found that students showed improvement in their vocabulary enrichment while learning under the cooperative learning approach and there was a significant difference in the students' pre-test and post-test scores. Additionally, the students had enhanced motivation and confidence within the learning group and through collaborating with peers, as discussed earlier in chapter 2 (Fekri, 2016).The findings were in agreement with the Van Wyk, (2012)study which showed a direct correlation between group learning and an increase in the motivation 
and confidence levels of the participants, clearly signifying that curriculum planning and teacher development must take into consideration the role of these approaches in major decision making policies. The results of our study are in accordance with the findings of Tok (2012) in which he investigated the association between CL and English language acquisition at the secondary level. The empirical research as well as the review of literature shows that it is required for successful implementation of CLA.

As the students improved their vocabulary and performed better after learning in CLA, the teachers need to be orientated and trained to be able to incorporate the CLA method into their teaching practices.

\section{RECOMMENDATIONS}

Further studies on CLA can be conducted to check the proficiency development of the grammar, communication or writing skills. Further studies should be done in order to review and investigate the provision of management and Practical tools.

\section{REFERENCES}

Ahmad, J. (2012). Intentional vs. incidental vocabulary learning. ELT Research Journal. 1(1): 67-75.

Badger, J., \& Warsi, J. (2009). The Importance of Identifying and Communicating Sophisticated Vocabulary Strategies. The Journal of Higher Education Management, 24(1), 33.

Berne, J. I., \&Blachowicz, C. L. (2008). What reading teachers say about vocabulary instruction: Voices from the classroom. The reading teacher, 62(4), 314-323.

ÇOKPARLAMIŞ, A. (2010). Effects of cooperative learning on teaching English to young learners.

Creswell, J. W., \& Plano Clark. (2011). Best practices for mixed methods research in the health

sciences. Bethesda (Maryland): National Institutes of Health, 2013, 541-545.

Dar, (2015) 'ESL learners' writing skills: Problems, factors and suggestions.” Journal of Education and Social Sciences.

Dovey, T. (2010). Facilitating writing from sources: A focus on both process and product. Journal of English for Academic Purposes, (9), 45-60

Ercan, E. E. (2009). Teaching vocabulary through cooperative learning (Master's thesis, Selçuk

ÜniversitesiSosyalBilimlerEnstitüsü).

Fan, M. Y. (2003). Frequency of use, perceived usefulness, and actual usefulness of second language vocabulary strategies: A study of Hong Kong learners. The Modern Language Journal, 87(2), 222-241.

Fekri, N. (2016). Investigating the Effect of Cooperative Learning and Competitive Learning 
Strategies on the English Vocabulary Development of Iranian Intermediate EFL Learners. English Language Teaching, 9(11), 6.

Heggins, M. (2015). Vocabulary Acquisition in English Language Learners (Doctoral dissertation, Northwest Missouri State University).

Jenkins, J. (2006). Current perspectives on teaching world Englishes and English as a lingua franca. TESOL quarterly, 40(1), 157-181.

Johnson, D. W., \& Johnson, R. T. (2009). Learning together and alone. Cooperative, competitive, and individualistic learning.

Khan, S. A., \& Ahmad, R. N. (2014). Evaluation of the Effectiveness of Cooperative Learning Method versus Traditional Learning Method on the Reading Comprehension of the Students. Journal Of Research \& Reflections In Education (JRRE), 8(1).

Lewis, M. (2006). L2 Vocabulary acquisition through extensive reading. Cambridge: Cambridge University Press.

Liang, T. (2002). Implementing cooperative learning in EFL teaching: Process and effects. Unpublished PhD dissertation. National Taiwan Normal University. Retrieved from http://www. Uefap. com/index. htm.

Lv, Y. (2014). Cooperative Learning: An Effective Approach to College English Learning. Theory and Practice in Language Studies.

Mahmood, N., \& Ahmad, Z. (2010). Effects of cooperative learning vs. traditional instruction on prospective teachers' learning experience and achievement.

Mansoor, S. (2003). Language Planning in Higher Education: Issues of Access and Equity. Lahore School of Economics Journals, 8(2)

McDonald, M. (2008). Back to the future: Directions for research in teaching and teacher education.

Mohseny, A. \&Jamour, F. (2012) The impact of student team achievement division on vocabulary learning of Iranian EFL pre-intermediate learners. International Electronic Journal for the Teachers of English, 2(6), 105-129.

Montasser, M. A. W. M. (2014). The Effectiveness of Using the Cooperative Language Learning Approach to Enhance EFL Writing Skills among Saudi University Students. Journal of Language Teaching and Research, 5(3), 616-625.

Shamim, F. (2008). Trends, issues and challenges in English language education in Pakistan. Asia Pacific Journal of Education, 28(3), 235-249.

Slavin, R.E. (1995). Cooperative learning: Theory, research, and practice (2nd Ed.). Boston: Allyn \& Bacon.

Sripramong, S. (2004). The study of the effect of using vocabulary games on the retention in learnin vocabulary of Prathomsuksa five students.Unpublishedmaster'thesis. Srinakharinwirot University. Thailand.

Tok, H. S. (2012) Cooperative learning and achievement in English language acquisition in a literature class in a secondary school. Unpublished Master Dissertation, University Teknologi Malaysia, Malaysia.

Van Wyk, M.M. (2012). The effects of the STAD-cooperative learning method on student achievement, attitude and motivation in economics education. Journal of Social Science, 33(2), 261-270

Windasari, W. Improving English Vocabulary Mastery Of Grade VIII Students Through 
Student Team Achievement Division (Stad) Method. e-Journal of ELTS (English Language Teaching Society), 4(2).

Woolley, G. (2010). A multiple strategy framework supporting vocabulary development for students with reading comprehension deficits. Australasian Journal of Special Education, 34(02), 119-132.

Zarei, A.A., \&Keshavarz, J. (2011). On the effects of two models of cooperative learning on EFL reading comprehension and vocabulary learning. Modern Journal of Language Teaching Methods, 1(2), 39-51. 